\title{
Zmiany w polityce obronnej wybranych państw Unii Europejskiej w latach 2014-2017
}

\begin{abstract}
Wstęp
Zaskoczenie strategiczne roku 2014 wpłynęło na wiele zmian w politykach obronnych i bezpieczeństwa państw europejskich, przynajmniej w warstwie deklaracji i dokumentów programowych. Zadaniem autora jest skoncentrowanie się na kilku przykładach państw Starego Kontynentu wybranych z grupy członków Unii Europejskiej. Jeszcze na przełomie pierwszej i drugiej dekady XXI wieku, m.in. w efekcie kryzysu gospodarczego, doszło do znacznych redukcji wydatków na obronność, jak wskazywali analitycy, groźnych dla utrzymania wystarczających zdolności wojskowych państw europejskich (Brune, Mölling, 2011). Wcześniej zaś np. w Belgii pojawiały się postulaty likwidacji sił zbrojnych, jako zbędnych temu państwu ze względu na jego położenie oraz charakter zagrożeń bezpieczeństwa, z jakimi mierzy się świat w XXI wieku. Daleko idące redukcje wydatków na zbrojenia w połączeniu z przekonaniem znacznej części społeczeństw, że bezpieczeństwo i obronę zagwarantują małe armie zawodowe wystarczające do rozwiązywania niewielkich, lokalnych konfliktów ${ }^{1}$, w połączeniu z gwarancjami bezpieczeństwa ze strony USA, sprawiły, że gro państw europejskich utraciło swe zdolności militarne. Przykład Niemiec jest tutaj bardzo znaczący, a stan zapaści ich sił zbrojnych jest powszechnie znany. Wydarzenia roku 2014 doprowadziły do zmian w obszarze polityki obronnej, na której należy się skoncentrować. W niektórych wypadkach ograniczyły się one do uświadomienia sobie braków i deklaracji dotyczących ich likwidacji, w innych do podjęcia działań, wprowadzania w życie nowych projektów, które mają uczynić armię narodową silniejszą, zdolną do prowadzenia działań samodzielnie oraz w ramach sojuszniczej operacji obronnej. W tym miejscu można postawić śmiałą i być może prowokacyjną tezę, a mianowicie stwierdzić, że wydarzenia 2014 roku stały się szansą dla państw europejskich i Unii Europejskiej na to, by odbudować lub zbudować swoje zdolności obronne. Autor dokona wyodrębnienia kilku państw, których zmiany w polityce obronnej można uznać za ilustrujące ten problem. By tego dokonać wykorzystane zostaną dane na temat wydatków na obronność publikowane przez wiarygodne instytuty zajmujące się analizą tej problematyki oraz dokumenty i raporty wydawane w państwach poddawanych analizie.
\end{abstract}

${ }^{1}$ Silne od czasów zakończenia zimnej wojny, które pozwoliło na skorzystanie z tzw. dywidendy pokojowej, a zatem środków finansowych, których nie trzeba było już kierować na zbrojenia, czego formalnym potwierdzeniem były zawarte traktaty dotyczące rozbrojenia i kontroli zbrojeń, także sił konwencjonalnych. To miało gwarantować minimalizację prawdopodobieństwa wybuchu wojny światowej czy ponadregionalnej. 


\section{Ujęcie calościowe}

Krzysztof Kubiak w jednej ze swoich publikacji dowiódł, że w wypadku państw europejskich sprawdzają się po zakończeniu zimnej wojny dwie reguły odnoszące się do ich sił zbrojnych. Po pierwsze, zmniejszenie ich stanów osobowych i związana z tym rezygnacja $\mathrm{z}$ obowiązkowej służby wojskowej. Po drugie zaś, gwałtowne obniżenie stanu posiadania sprzętu ciężkiego, co było związane z przekonaniem, że potrzebne będą siły mobilne, lekkie, zdolne do szybkich działań ekspedycyjnych. $Z$ tego też względu wielkość sił zbrojnych państw europejskich zdecydowanie zaczęła odbiegać od przyznanych im limitów zapisanych w Traktacie w sprawie konwencjonalnych sił zbrojnych w Europie (Kubiak, 2016, s. 24-27). Przyjmując, że ustalone limity uznawać należy za minimalne, których posiadanie jest niezbędne do utrzymania zdolności obronnych, można uznać, że państwa europejskie znalazły się zdecydowanie poniżej nich. Kubiak udowadnia to odpowiednimi danymi dotyczącymi liczebności sił zbrojnych i ich uzbrojenia zgodnie z danymi za 2015 rok. Dla przykładu Belgia może posiadać 70 tys. żołnierzy, a miała ich 17200,334 czołgi, a miała 0. Francja 325 tys. żołnierzy, a miała 167 tys., 1306 czołgów, a miała 254, Polska 234 tys. żołnierzy, a miała 91 tys., 1730 czołgów, a miała 974, Wielka Brytania 260 tys. żołnierzy, a miała 156 tys., 1015 czołgów, a miała 227 (Kubiak, 2016, s. 25-27). Te przykłady można mnożyć. Niech za ostatni posłuży wykres ilustrujący redukcję personelu wojskowego w państwach Unii Europejskiej.

Wykres 1. Zmiany wielkości personelu wojskowego w państwach UE (EDA)

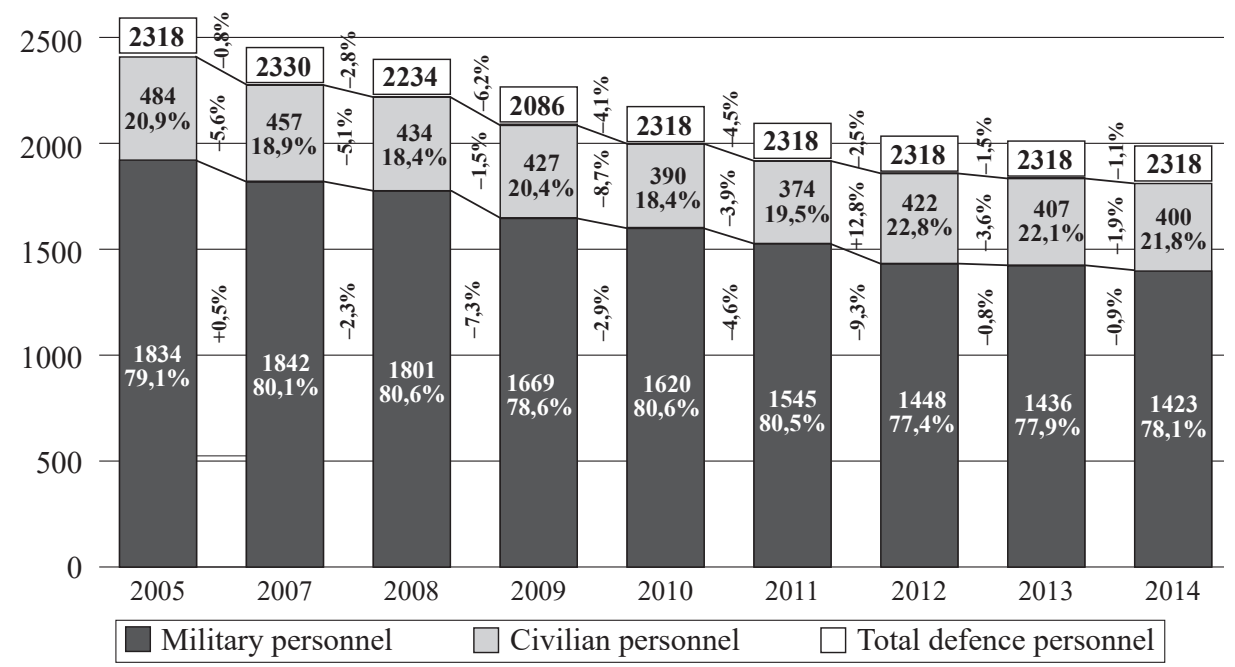

* Wzrost liczby personelu cywilnego w 2012 wynika ze zmiany sposobu liczenia dokonanej w jednym z państw członkowskich.

Źródło: Defence Data 2014, European Defence Agency 2016, s. 15.

Można zatem przyjąć, że państwa europejskie utraciły zdolności do prowadzenia działań zbrojnych w skali ponadregionalnej i regionalnej, o czym świadczą przykłady 
podejmowanych przez nie, lub nie, interwencji zbrojnych i ich przebieg np. w Libii, która pokazała fatalny poziom zdolności wojskowych najsilniejszych armii w Europie (szczególne Francji i Wielkiej Brytanii). Tym samym zasadne stały się pytania o ich zdolności do obrony własnego terytorium stawiane w kontekście wydarzeń z 2014 roku przez tych Europejczyków, którzy poczuli się zagrożeni agresywną polityką Federacji Rosyjskiej. Z tego m.in. względu prowadzono ciekawe badania opinii publicznej, które miały wskazać czy obywatele poszczególnych państw byliby gotowi walczyć w obronie innych. Rzecz ilustruje poniższa infografika.

\section{Infografika 1. Gotowość do okazania sojuszniczej solidarności w wybranych państwach NATO}

\section{Many NATO Countries Reluctant to Use Force to Defend Allies}

If Russia got into a serious military conflict with one of its neighboring countriesthat is our NATO ally, do you think our country should or should not use military force to defend that country?

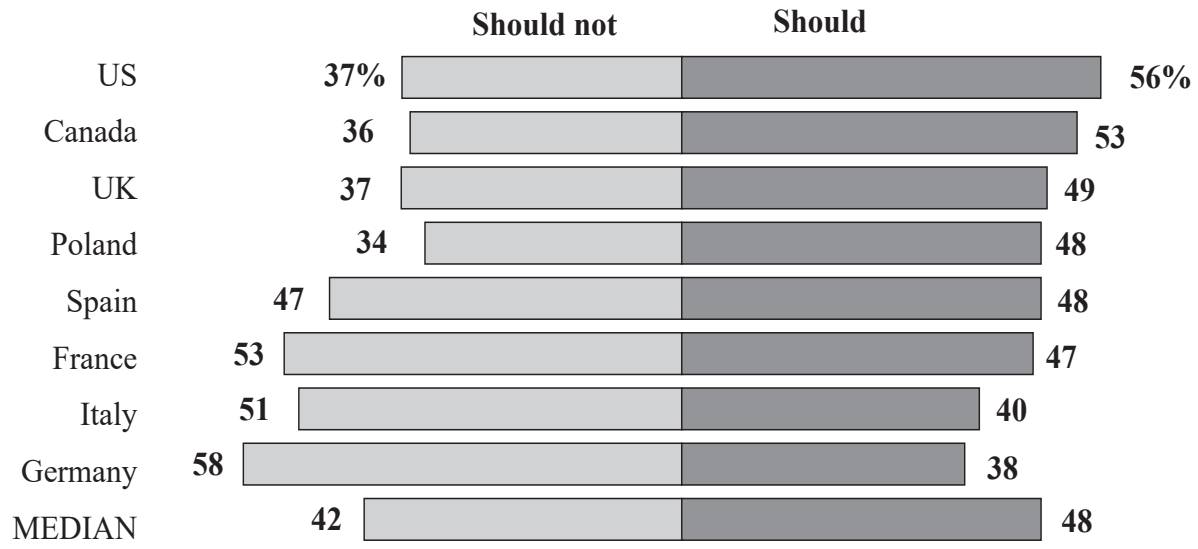

Źródło: http://www.pewresearch.org/fact-tank/2016/07/06/support-for-nato-is-widespread-among-member-nations/ft_16-7-6-nato4/.

Wyniki powyższych badań wskazują, że jedynie Amerykanie i Kanadyjczycy w swej większości gotowi są bić się za innych członków NATO. W tym wypadku europejskich właśnie. To pokazuje, jak duże luki w zdolnościach obronnych pojawiły się nie tylko w sferze materialnej, ale i mentalnej, woluntarystycznej, która może być traktowana jako jeszcze istotniejsza, szczególnie jeśli przyjąć za słuszne koncepcje tzw. wojny hybrydowej i nacisk, jaki kładzie się w nich na złamanie woli oporu przeciwnika, jeszcze przed rozpoczęciem działań zbrojnych. Sprzyjała temu rezygnacja z powszechnego poboru i związany z tym brak przeszkolenia wojskowego. Nowy kształt sił zbrojnych pozwolił zaś na zredukowanie żołnierzy biorących bezpośredni udział w walce. To wszystko sprawiło, że zdecydowanie mniej Europejczyków jest również mentalnie gotowych do walki. Wojskowi zaś są wąską grupą profesjonalistów, kosztowną w utrzymaniu, której nie wolno tracić. Przewagę daje im technika oraz wyszkolenie w jej użyciu. Gdy ta zawiedzie lub jest nieużyteczna, wtedy tracą swoją przewagę i narażają się na nieakceptowane społecznie straty. Tak można wyja- 
śnić otrzymane wyniki badań, które objęły tylko część państw europejskich, niestety tylko z jednym przedstawicielem Europy Środkowo-Wschodniej, jednak ich wyniki powinno się traktować jako przynajmniej powód do zastanowienia nad zmianami polityki obronnej, a szerzej bezpieczeństwa. Tym bardziej, że Europie Zachodniej (generalizując) od wielu lat towarzyszyła niechęć do użycia siły i bezradność wobec dziejących się nawet na starym kontynencie konfliktów, co wymuszało zaangażowanie USA. Przekonanie, że wszystko uda się rozwiązać pokojowo okazywało się niesłuszne, kiedy za dyplomacją nie stała siła inna niż ekonomiczna. Krzysztof Kubiak nazywa ten stan widoczny wśród wielu Europejczyków „Poheroicznym Zachodem” (Kubiak, 2016, s. 30-32), wskazując przede wszystkim na państwa zachodu Europy, jako te, dla których przemiany związane z końcem zimnej wojny nie oznaczały wolności (niepodległości), a jedynie koniec czasu konfrontacji i szansę na kolejny etap poprawy jakości życia. Taki Zachód spotkał się w 2014 roku z agresją Federacji Rosyjskiej na Ukrainę. Owe zjawisko widać wyraźnie na poniższych wykresach ilustrujących zmiany, jakie zaszły w dziedzinie wydatków na obronność w państwach Unii Europejskiej po 2014 roku.

\section{Infografika 2. Wzrost wydatków na obronność w państwach Unii Europejskiej (EDA)} w latach 2014-2016

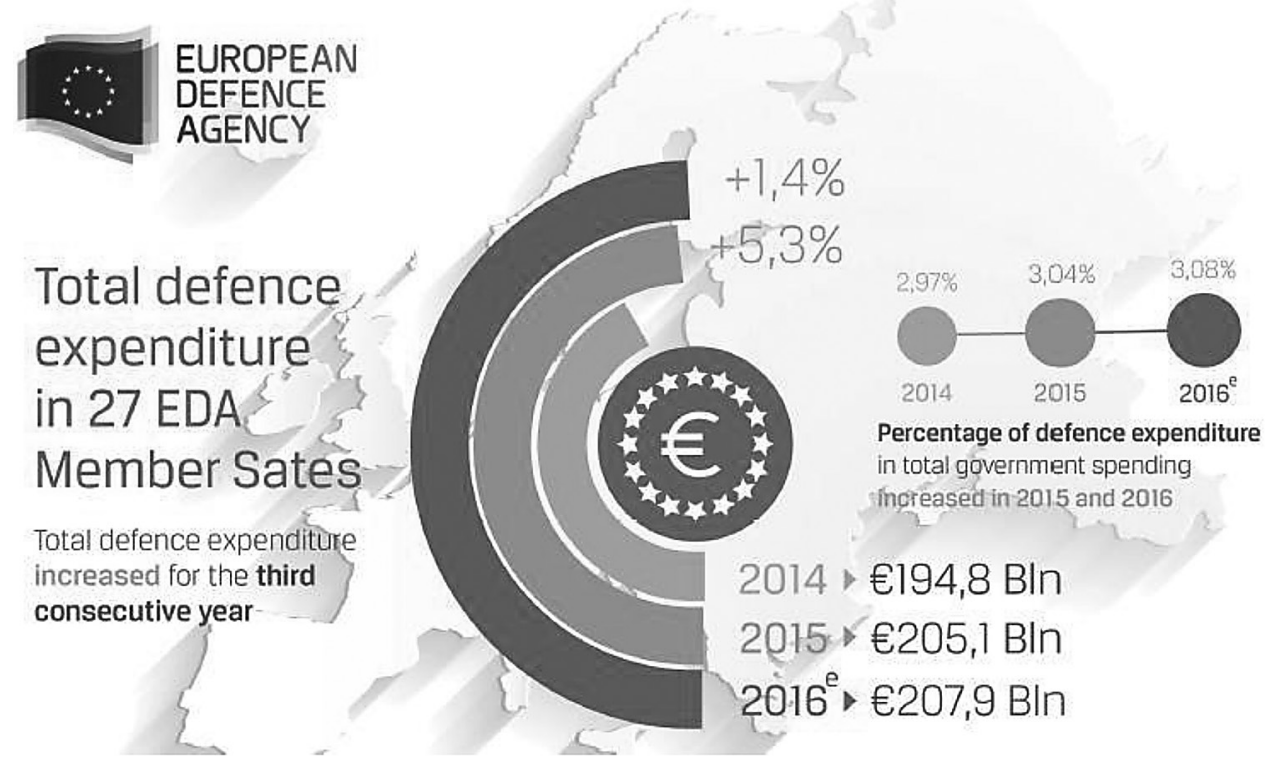

Źródło: Total defence expenditure In 27 EDA Member States, EDA factsheet.

Widać wzrost wydatków na obronność sięgający nieco ponad 13 mld $€$. Nie jest to kwota wielka, biorąc pod uwagę, że dotyczy łącznie 27 państw. Nadto, nie może w szybki sposób doprowadzić do nadrobienia zaległości, jakie powstały w armiach państw unijnych. Przy tym w 2016 roku tylko 4 państwa Unii wydawały na obronność więcej niż $2 \%$ PKB, ale 18 z 27 podniosło swoje wydatki, nawet jeśli jedynie sym- 
bolicznie (European Defence Agency, 2018, s. 6). Co ciekawe, luka pomiędzy wydatkami, gdyby wynosiły one w każdym państwie minimum 2\% PKB, a osiąganymi w 2016 roku wynosiła 88 mld € (European Defence Agency, 2018, s. 7). Jest to zatem olbrzymia kwota wskazująca, jak mało łożą na obronność państwa nie tylko należące do Unii, ale i europejskie państwa NATO, z których większość należy do UE. Warto postawić pytanie, w których państwach nastąpił wzrost wydatków? Czy jakaś część, region, wyróżnia się pod tym względem? Europejska Agencja Obrony (EDA) podaje dane na ten temat.

\section{Wykres 2. Wydatki na obronność wg regionów w Unii Europejskiej (EDA)}

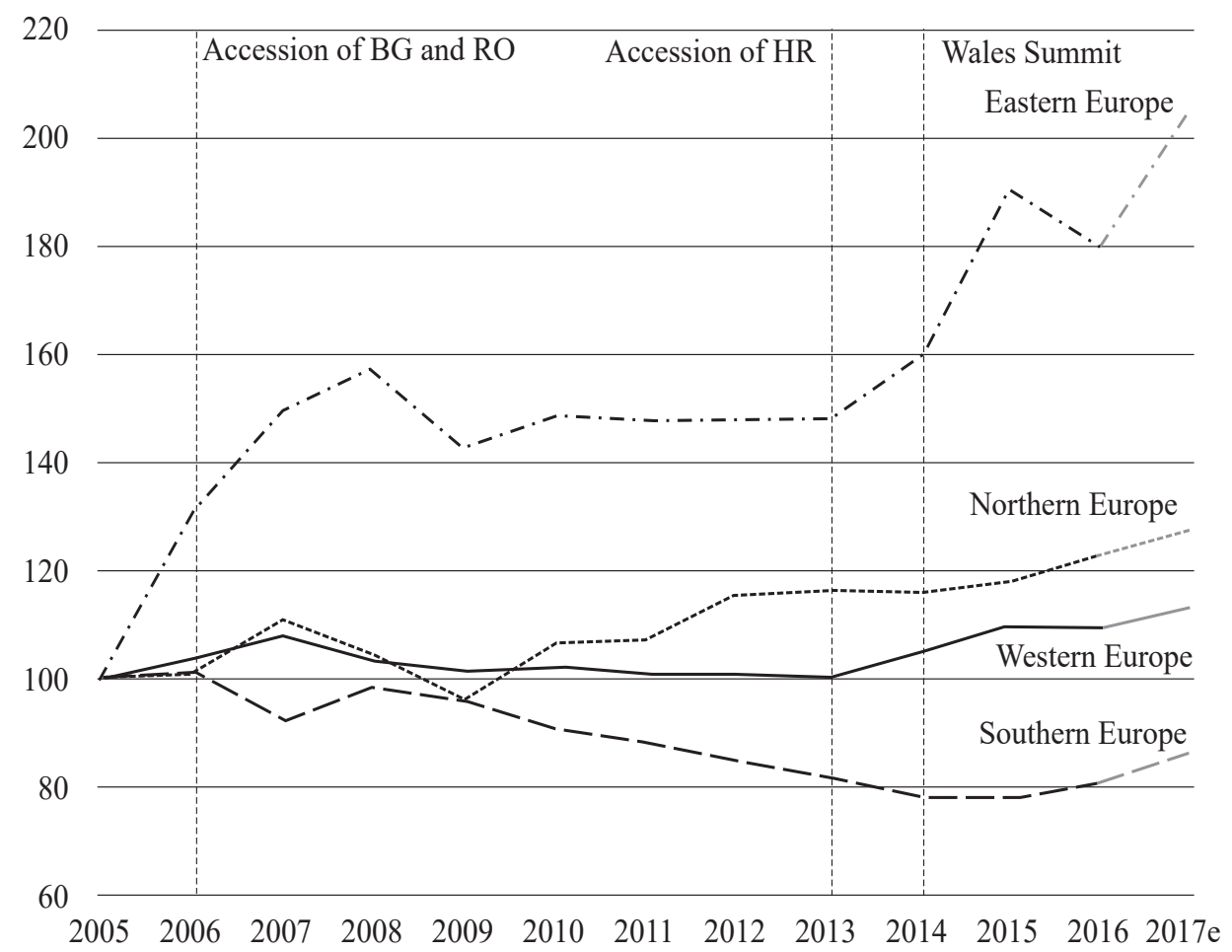

Źródło: Defence Data 2016-2017, Key Findings and Analysis, European Defence Agency 2018, s. 8.

Przedstawiony wykres dowodzi słuszności postawionej wcześniej tezy dotyczącej wydatków i znaczenia obronności dla państw Wschodniej Europy. Dodatkowo zaś ich szybki wzrost po 2014 roku, nieporównywalny do zmian, jakie zaszły w pozostałych państwach. Szacunki EDA wskazują na utrzymanie tego trendu, po chwilowym obniżeniu wydatków w okresie 2015-2016. Ów spadek dobrze widoczny jest na wykresie 3.

Autor przedstawił najbardziej aktualne dane publikowane przez EDA. Szacunki Agencji wskazują na wzrost wydatków po 2016 roku. Jednak obserwowana chwiejność rządów w tym obszarze czyni te przewidywania ryzykownymi. Można stwierdzić, że jest to jeden z powodów, dla których administracja Donalda Trumpa tak silnie podkreśla konieczność wzrostu nakładów na obronność ponoszonych przez europej- 
skich członków NATO. Efekty tych apeli są różne, o czym czytelnika nie trzeba przekonywać.

\section{Wykres 3. Wydatki na obronność państw Unii Europejskiej (EDA)}

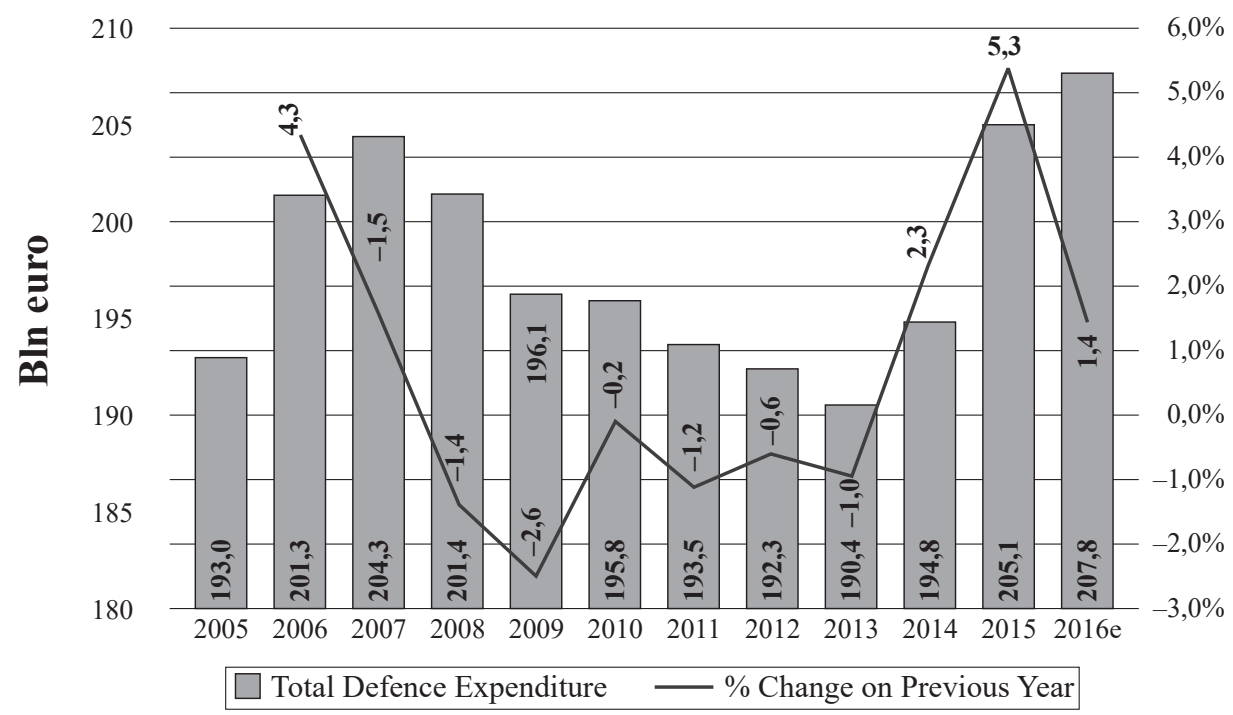

Źródło: Defence Data 2006-2016, European Defence Agency 2017, s. 4.

Przechodząc do dalszej części analizy Autor zdecyduje się na wybór przykładów państw zależnie od wskazanych przez EDA regionów UE. Zatem Północnego, Wschodniego, Zachodniego i Południowego. Krótko zostaną przedstawione założenia polityki obronnej zamieszczone w aktualnie obowiązujących dokumentach oraz przykłady działań rządów podejmowanych w tym obszarze.

\section{Region Pólnocny, Finlandia}

Wydarzenia na Ukrainie stały się powodem przeglądu i zmian w fińskiej polityce obronnej. Aktualnie obowiązująca znajduje się w Government Defence Report, 2017 (Government's 2017). Autorzy dokumentu za kluczowe kwestie dotyczące obronności Finlandii uznali:

- zmiany w międzynarodowym środowisku bezpieczeństwa (w szczególności okupacja Krymu, konflikt we wschodniej Ukrainie, napięcia w basenie Morza Bałtyckiego i polityka Federacji Rosyjskiej chcącej odzyskać status światowego mocarstwa) powodują, że wzrastają możliwości podjęcia wrogich działań wobec Finlandii, co wymusza większe zainteresowanie polityką obronną. Konieczny jest wzrost gotowości do działania sił zbrojnych, co wymusza skierowanie dodatkowych środków na obronność od 2018 roku;

- należy przygotować się na wrogie operacje w cyberprzestrzeni, w szczególności cyberataki i oddziaływanie psychologiczne, ponieważ stanowią one coraz większe 
zagrożenie dla bezpieczeństwa i obronności państwa, co jest związane z postępem technologicznym, w efekcie którego społeczeństwa stają się zależne od nowoczesnych technologii i podatne na ich oddziaływanie;

- duże znaczenie ma współpraca obronna z innymi państwami, w szczególności Szwecją i Stanami Zjednoczonymi Ameryki. Finlandia pozostaje aktywna w rozwoju współpracy w zakresie bezpieczeństwa i obronności pomiędzy państwami Unii Europejskiej. Nie przewiduje się jednak wstąpienia do jakiegokolwiek sojuszu militarnego, mimo rozwoju współpracy z NATO. W dalszej kolejności jako partnerzy wymieniane są inne państwa Unii Europejskiej, m.in. Polska;

- w związku z ograniczeniem wydatków na obronność i przeprowadzoną reformą w tym obszarze w latach 2012-2014 konieczne jest zwiększenie środków przeznaczonych na rozwój sił zbrojnych, ponieważ nie są one w stanie zapewnić właściwej odpowiedzi na istniejące zagrożenia. Oznacza to przede wszystkim inwestycję w rozwój zdolności sił zbrojnych do szybkiego reagowania na zagrożenia oraz posiadanie dużych, przeszkolonych rezerw. Finlandia musi być bowiem gotowa na „odparcie ataku o dużej skali” (repel a large-scale attack) oraz różnego rodzaju działań militarnych i niemilitarnych, często połączonych, poniżej progu wojny (Government's, 2017, s. 15). Szczególną rolę w przygotowaniach do odparcia ataku na wielką skalę odgrywa duża, przeszkolona rezerwa;

- źródłem obronności państwa jest silne przekonanie obywateli o potrzebie jego obrony, pobór i wynikające $\mathrm{z}$ tego powszechne przeszkolenie wojskowe oraz współpraca wszystkich instytucji, zarówno cywilnych, jak i wojskowych, na rzecz obronności. W drugiej kolejności jest nim przygotowanie do wykorzystania pomocy z zewnątrz, czemu służy udział Finlandii w międzynarodowej współpracy wojskowej. Przy założeniu, że nie gwarantuje ona otrzymania pomocy z zewnątrz, ale że siły zbrojne mają być przygotowane na jej przyjęcie;

- zadaniem rezerw jest zapewnienie regionalnej obecności i obrony, także w sytuacji kryzysowej, konieczne jest przy tym przygotowanie do prowadzenia operacji połączonych, jako niezbędnych współcześnie i wymaganych także od obrony terytorialnej na poziomie regionalnym. Oznacza to także uwzględnienie współpracy z innymi instytucjami, nie tylko wojskowymi, zgodnie z koncepcją „obrony totalnej”;

- siły zbrojne podzielone są na część manewrową (operacyjną), regionalną i lokalną. Siły regionalne zapewniają ,,pokrycie" (depth and nation-wide coverage) obronne w przypisanym im regionie, a łącznie całości lądowego terytorium państwa. Siły lokalne zapewniają wsparcie siłom manewrowym (operacyjnym) i regionalnym w swoim obszarze odpowiedzialności, biorąc udział w działaniach bojowych. Ich działanie oparte jest o założenia Doktryny działań wojsk lądowych oraz Doktryny działań sił regionalnych i lokalnych, która zostanie dopasowana do aktualnych potrzeb obronności;

- siły zbrojne będą rozwijały zdolności do działań obronnych w cyberprzestrzeni;

- system i program szkolenia rezerw zostanie dostosowany do wymagań związanych z użyciem siły w czasie kryzysu, pobór zostanie utrzymany, wraz z rozwojem zachęt do ochotniczej służby kobiet;

- pozostawanie przy fundamencie polityki obronnej, jaką jest przekonanie każdego Fina o konieczności obrony ojczyzny, w czym swój udział mają organizacje pozarządowe, co jest wspierane przez państwo. 
Widać wyraźnie, że twórcy polityki obronnej Finlandii przyjęli konieczność nasycenia terenu siłami przygotowanymi do prowadzenia działań obronnych uwzględniając skalę lokalną i regionalną. Czyniąc masowość przeszkolenia wojskowego głównym filarem siły obronnej państwa zorganizowanym wokół wojsk regionalnych, jako struktury odpowiedzialnej za zagospodarowanie rezerwistów i ich planowe wykorzystanie podczas działań zbrojnych. Ich obecność w terenie ma stanowić także kluczowy atut w odparciu ewentualnych działań hybrydowych (poniżej progu wojny).

Zgodnie z powyższymi założeniami fińskie siły zbrojne mają być niewielkie w czasie pokoju, ale błyskawicznie rozwijane na wypadek wojny, na co pozwolić mają odpowiednio zorganizowane wojska obrony terytorialnej (zwane Siłami Terytorialnymi Maakuntajoukot, które utworzono w 2007 roku), stanowiące główną część sił zbrojnych i zapewniające możliwość szybkiej mobilizacji. W 2017 roku na czas wojny siły zbrojne liczyć miały 230 tys. żołnierzy, z tego w wojskach lądowych 150 tys., 60\% z nich stanowić mają Siły Terytorialne, podczas gdy wojska operacyjne i lokalne po 20\% (Finnish, 2017, s. 9). Natomiast do 2020 roku ma to być 280 tys. Podstawowe przeszkolenie zapewnia pobór, którą to instytucję zapisano w konstytucji w artykule 127. Finowie w zdecydowanej większości popierają pobór, przez który przechodzi 80\% mężczyzn, a wg danych z 2016 roku nieco ponad 76\% mężczyzn było gotowych walczyć w obronie ojczyzny (Järvenpää, 2016, s. 6). Nie przez przypadek ulotka zachęcająca do służby wojskowej nosi tytuł National defence is everybody's business (The Finnish Defence Forces, 2017). Wiek poborowych określono na od 18 do 60 lat, a okres służby na 165, 255 lub 347 dni, zależnie od przeznaczenia poborowego (podstawowe, medyczne i specjalistyczne). Możliwe jest odbycie służby zastępczej trwającej 347 dni, z czego z różnych przyczyn korzysta ok. 6\% poborowych. Od 1995 roku także kobiety w wieku od 18 do 29 lat mogą zgłosić się na ochotnika do służby w siłach zbrojnych lub straży granicznej. Średnio co roku zgłasza się ok. 525 kobiet. Co istotne, po zakończeniu służby organizowane są ćwiczenia (odświeżające), w których rezerwiści muszą brać udział. Liczba rezerwistów szacowana jest na ok. 900 tys. (Finnish, 2017, s. 16). Co stanowi nieco mniej niż 1/5 wszystkich mieszkańców Finlandii. W 2015 roku przyjęto plan natychmiastowego powoływania 25 tys. rezerwistów w wieku od 20 do 25 lat, którzy będą członkami jednostek szybkiego reagowania w czasie swojej służby jako poborowi i podpiszą odpowiednią umowę z siłami zbrojnymi co do swojej gotowości do działania. Była to odpowiedź na wydarzenia na Ukrainie, do której warto zaliczyć także dwukrotne zwiększenie liczby rezerwistów powoływanych na ćwiczenia odświeżające, z 18 do 36 tys. Za ich przeprowadzanie odpowiedzialne są wojska operacyjne. Istnieje także rozwinięta współpraca z organizacjami pro obronnymi. Wszystko to sprawia, że Finlandia jest państwem przygotowującym się do obrony totalnej i wykorzystującej posiadane przez to państwo atuty. Konflikt zbrojny na Ukrainie ograniczył politykę oszczędności wydatków na obronę i zmienił kierunek działań ze zmniejszających na zwiększające zdolności sił zbrojnych. Jednak nie zwiększono wydatków na obronność liczonych jako procent PKB. Zgodnie z dostępnymi danymi Ministerstwa Obrony Finlandii wynosiły one w 2014 roku 1,3\%, 2015 roku 1,29\%, 2016 roku 1,31\%, 2017 1,26\% i w 2018 roku przewidziano 1,23\%. Mimo tego w liczbach bezwzględnych wydatki się zwiększą z 2829 mln € w 2017 roku do $2872 \mathrm{mln} €$ w 2018 roku. W 2014 roku wynosiły 2670,8 mln € (Ministry of Defence, 2018). Biorąc 
to pod uwagę można stwierdzić, że nie doszło do radykalnego wzrostu wydatków, a tym samym znaczącego podniesienia poziomu zdolności obronnych. Udział wydatków w budżecie zmniejsza się, utrzymując ilość wydatkowanych pieniędzy na podobnym poziomie. Zatem realizacja nakreślonych planów rozwoju ma odbywać się przy wykorzystaniu podobnej wielkości środków, jakie wydawano wcześniej.

\section{Region Wschodni, Polska}

Podobnie jak w Finlandii, także i w Polsce aneksja Krymu oraz konflikt zbrojny na wschodzie Ukrainy w połączeniu z przejęciem władzy przez Prawo i Sprawiedliwość doprowadziły do przeglądu dotychczas prowadzonej polityki obronnej. Przygotowano Strategiczny Przegląd Obronny, którego jawną wersją (prezentującą fragmenty Przeglądu?) jest wydana w maju 2017 roku Koncepcja Obronna Rzeczypospolitej Polskiej. Treść dokumentu odzwierciedla percepcję środowiska międzynarodowego przez ówczesne władze RP oraz przedstawia założenia polityki obronnej Polski w perspektywie do 2032. W sposób syntetyczny rzecz można ująć następująco:

- odnotowano sprzeciw wobec globalizacji i jej skutków, jako jeden z trendów obecnych w środowisku międzynarodowym, ponadto próby podważania obecnego ładu międzynarodowego, szczególnie pozycji USA, łącznie z możliwą ekspansją terytorialną z tym związaną, rośnie znaczenie nowych potęg gospodarczych, a zmniejsza się Zachodu, podobnie coraz istotniejszymi uczestnikami stosunków międzynarodowych stają się aktorzy pozapaństwowi, możliwe jest w przyszłości zwiększenie ilości międzynarodowych misji humanitarnych ze względu na zmiany społeczne zachodzące w wielu państwach powodujące np. migrację, wreszcie postęp technologiczny może także powodować negatywne konsekwencje dla bezpieczeństwa narodowego i międzynarodowego;

- za najważniejsze zagrożenia dla bezpieczeństwa Polski uznano agresywną politykę Federacji Rosyjskiej, która, jak założono, będzie trwała minimum do 2032 roku (Ministerstwo Obrony Narodowej, 2017, s. 21), niestabilne sąsiedztwo wschodniej flanki NATO (np. sytuacja wewnętrzna na Ukrainie), niestabilne sąsiedztwo południowej flanki NATO (np. kolejne fale migracyjne), terroryzm, ewolucję zachodnich struktur integracyjnych (tak by np. skierować NATO na koncentrację na obronie kolektywnej, a nie ekspedycyjności), zmiany w otoczeniu ekonomicznym i społecznym (m.in. zapewnienie właściwej wysokości wydatków na obronność) oraz postęp technologiczny i przyszła przestrzeń walki (np. cyberprzestrzeń, pole walki informacyjnej);

- NATO, Unia Europejska i USA mają odgrywać rolę najważniejszych partnerów w dziedzinie obronnej, ze szczególną rolą rozwoju współpracy dwustronnej z USA, dalej za istotną uznano współpracę z państwami regionu, szeroko rozumianego, zarówno Europy Północnej, jak i państwami Grupy Wyszehradzkiej, dostrzeżono perspektywy współpracy z Niemcami i Wielką Brytanią;

- biorąc pod uwagę powyższe założenia, siły zbrojne mają skoncentrować się na obronie terytorium RP, samodzielnej, dysponując, jak to ujęto: „po raz pierwszy we współczesnej historii Polski [...] efektywnym potencjałem odstraszania" (Mi- 
nisterstwo Obrony Narodowej, 2017, s. 38) oraz wspólnie z sojusznikami (kolektywna operacja obronna), możliwy jest także udział w operacjach koalicyjnych i ONZ poza granicami państwa realizując misje w celu wzmacniania stabilności ładu międzynarodowego, podkreślono także znaczenie operacji reagowania kryzysowego i posiadania zdolności do współpracy z innymi „służbami” (Ministerstwo Obrony Narodowej, 2017, s. 39);

- wprowadzane zmiany w siłach zbrojnych mają mieć charakter defensywny, liczba żołnierzy ma zostać zwiększona do 250 tys. do ok. 2025-2030 roku, zatem ponad dwukrotnie w porównaniu ze stanem, w jakim rządy PiS je zastały. Planuje się utworzenie nowej dywizji. Ponadto mają przejść intensywny proces modernizacji, w szczególności w obszarze obrony przeciwlotniczej i przeciwrakietowej, środków rozpoznania, artylerii, obrony przeciwpancernej, śmigłowców szturmowych, lotnictwa bojowego, zakupu nowych okrętów itd. Lista jest bardzo długa i obejmuje praktycznie całe istotne wyposażenie sił zbrojnych. Ma zostać wprowadzony nowy system kierowania i dowodzenia Siłami Zbrojnymi RP;

- położono nacisk na rozwój Wojsk Specjalnych oraz Wojsk Obrony Terytorialnej (WOT), które mają działać samodzielnie lub we współpracy z pozostałymi rodzajami sił zbrojnych. WOT ma posiadać zdolności do operowania na tyłach wroga, gdyby była taka konieczność. Generalnie zaś wszystkie rodzaje sił zbrojnych mają być gotowe do prowadzenia operacji połączonej, z naciskiem na wojska operacyjne i WOT, co ma zostać wypracowane poprzez system ćwiczeń i gier wojennych. Kluczowymi zaś dla polskiej obronności pozostawać mają Wojska Lądowe i Siły Powietrzne;

- w planach obronnych ma być uwzględniany potencjał całego państwa, nie tylko MON i Sił Zbrojnych RP, ponadto zaś dla podniesienia ich jakości rozbudowie ulegną zdolności analityczne MON;

- środki na modernizację wojska mają pochodzić z budżetu państwa, ponieważ do 2030 roku ilość wydawanych środków ma osiągnąć poziom 2,5\% PKB (już po wydanym dokumencie Prezydent RP Andrzej Duda wyraził nadzieję, że stanie się to szybciej).

Widać wyraźnie, że rządzący Polską zdecydowali o zwiększeniu ilościowym sił zbrojnych i poprawie jakości wyposażenia i uzbrojenia, jako koniecznych do posiadania odpowiedniego potencjału obronnego państwa. Siły Zbrojne RP w 2032 roku mają być jednymi z najsilniejszych w Europie. Założono realizację bardzo ambitnych planów w tym zakresie, biorąc pod uwagę nie tylko czynniki ekonomiczne, ale i demograficzne. Dodatkowo zaś uwzględnione zostały doświadczenia dotyczące realizacji programów modernizacyjnych w siłach zbrojnych, w szczególności sprawności prowadzenia przetargów. Jednak kluczowe będzie połączenie rozrostu ilościowego ze zmianą jakościową, które ma odbywać się równolegle. To zadanie bardzo ambitne, które można zrealizować planowo tylko w perspektywie kilku kadencji, a kontynuowanie tego programu przez partie opozycyjne stoi pod znakiem zapytania, o czym świadczy negowanie budowy WOT przez Platformę Obywatelską. Problem pogodzenia obu kierunków zmian wyraźnie ilustruje powołanie nowej dywizji, której dowództwo zostało umieszczone w Siedlcach. Decyzję ogłoszono $\mathrm{z}$ wielkim rozmachem, niemającym uzasadnienia $\mathrm{w}$ rzeczywistym wzmocnieniu 
potencjału obronnego państwa. W skład nowej Dywizji weszły dwie już istniejące brygady, brakuje trzeciej oraz jednostek wsparcia. W związku z tym na razie jest to tylko nowa struktura, która czeka na wypełnienie treścią. Ale przyjmując, że budowa zdolności wojskowych jest procesem, należy oczekiwać, że nowa Dywizja zyska odpowiednie zdolności w bliżej nieokreślonej przyszłości.

O tym, że Siły Zbrojne RP mają mieć zdolności przede wszystkim do obrony własnego terytorium i na tym koncentrować mają się wysiłki na rzecz budowy ich zdolności, świadczy rozpoczęcie i realizacja projektu budowy Wojsk Obrony Terytorialnej (Klisz, Lasoń, 2017). Mają liczyć ponad 50 tys. żołnierzy, służących w ramach terytorialnej służby wojskowej, pozwalającej łączyć życie zawodowe ze szkoleniem wojskowym i wynikającą z tego służbą. Przede wszystkim na rzecz obrony i ochrony społeczności lokalnych poprzez udział w działaniach obronnych oraz operacjach reagowania kryzysowego. Dodatkowo zaś ważnym ich zadaniem jest budowa świadomości patriotycznej. WOT ma liczyć 17 brygad umieszczonych w każdym województwie, z czego dwie znajdą się w Mazowieckim. W każdym powiecie ma być zaś jedna kompania WOT. W ten sposób środowisko walki ma być nasycone obecnością żołnierzy znających je doskonale ze względu na to, że są mieszkańcami tych okolic. Trzeba podkreślić, że tworzenie WOT jest procesem, a wobec tego znaczna część krytyki kierowanej wobec tej formacji jest przedwczesna. Konieczne jest zakończenie procesu formowania i szkolenia pierwszych jednostek, następnie dokonanie przeglądu doświadczeń z tym związanych i wdrożenia wniosków z tego płynących. Dodatkowo odbudowa niezbędnej infrastruktury i rozwiązanie szeregu problemów, jakie pojawiły się w związku z tworzeniem tego typu formacji, a wynikają m.in. z wcześniejszego obniżania potencjału Wojska Polskiego. Dodatkowo związane są z kojarzeniem tej formacji z rządem Prawa i Sprawiedliwości, przede wszystkim Ministrem Obrony Narodowej Antonim Macierewiczem, który pełniąc tę funkcję był promotorem szybkiego rozwoju WOT. Jest to przykład politycznego uwikłania kwestii obronnych w bieżącą rywalizację pomiędzy głównymi siłami politycznymi i braku spójnego, ponadpartyjnego consensusu w tym zakresie.

Te niezwykle ambitne założenia wpisują się w cały program polityczny rządu Prawa i Sprawiedliwości. Wydatki na obronność w 2014 roku wynosiły 31874 mln zł, podczas gdy w 2018 roku zaplanowano wydanie 41779 mln zł. Jest to więc znaczący wzrost w ciągu 4 lat. Jednak od czasu przejęcia władzy przez PiS jesienią 2015 roku wzrost nastąpił od poziomu $37082 \mathrm{mln}$ zł. Biorąc pod uwagę wskaźnik PKB odpowiednio w 2014 roku było to 1,85\%, w 2015 - 2,22\%, w 2016 - 2\%, w $2017-1,89 \%$ i w 2018 - 1,98\% (Defence Expenditure, 2018, s. 6 i 8). Zatem efektywne wydatki oscylują wokół 2\% PKB i nie zostały znacznie podniesione, ale istnieje co do tego deklaracja polityczna oraz rozwiązania przyjęte prawnie. Wobec tego Polska będzie dysponowała większymi środkami, które przeznaczy na realizację ambitnego projektu, jednak kwoty, choć mogą być uznawane za niewystarczające, nie są na tej drodze taką dużą przeszkodą, jak zdolność do efektywnego wydawania pieniędzy, z czym MON ma znaczne problemy. Podsumowując, od 2014 roku, w szczególności po 2015 roku, rozpoczął się w Siłach Zbrojnych RP proces daleko idących zmian, w pierwszej kolejności w wymiarze koncepcyjnym, ich wdrożenie zająć ma 15 lat, licząc początek od 2017 roku. 


\section{Region Zachodni, Holandia}

Władze Holandii były stymulowane do podjęcia decyzji o zwiększeniu wydatków na obronność nie tylko agresją Federacji Rosyjskiej na Ukrainę, ale i zestrzeleniem samolotu pasażerskiego linii malezyjskich, na pokładzie którego było wielu jej obywateli. To zdarzenie nie mogło przejść bez echa. W związku z tym już w projekcie budżetu na 2015 rok zadeklarowano niewielkie zwiększenie wydatków obronnych sięgające ok. $100 \mathrm{mln} €$ (Palowski, 2014). Sama kwota nie miała przy tym większego znaczenia. Liczył się fakt, że możliwe jest odwrócenie trendu spadkowego w tym obszarze. Tym bardziej, że doprowadził on do wycofania z eksploatacji czołgów oraz zmniejszenia liczby używanych samolotów F-16. Zapowiedziano także dalsze wzrosty wydatków o podobne kwoty, co nie mogło jednak doprowadzić do nadrobienia powstałych w latach poprzednich zaległości (Kołek, 2017). Władze Holandii zdały sobie z tego sprawę, czego świadectwem jest zawartość Białej Księgi Obronnej wydanej w 2018 roku sygnalizującej ten problem już w słowie wstępnym Ministra Obrony Holandii (Ministry of Defence, 2018, s. 3). Mowa w nim także o realizmie podejścia władz, zatem można domniemywać, że chodzi o pogodzenie możliwości budżetowych z wymaganiami współczesnego środowiska bezpieczeństwa. W tym kontekście możliwości budżetowe należy rozumieć jako spełnienie oczekiwań obywateli dotyczących wydatków na poszczególne sfery polityki państwa. Przedstawiając zawartość Białej Księgi w sposób syntetyczny należy wskazać na:

- za główne zadania sił zbrojnych uznano obronę terytorium Holandii wraz z terytoriami na Karaibach i całego NATO, wsparcie i ochronę porządku międzynarodowego opartego na prawie oraz wsparcie władz cywilnych, szczególnie w wypadku reakcji na katastrofy naturalne itp.;

- za najważniejsze trendy w środowisku bezpieczeństwa uznano zmiany geopolityczne, nierównowagę w wielkości populacji między regionami świata, rewolucję cyfrową, w tym zmiany w relacjach człowiek-maszyna, rosnący poziom kompleksowości zagrożeń bezpieczeństwa (ilustrowany rysunkiem terrorysty) i oczekiwania wobec Holandii stawiane przez sojuszników z NATO i państwa UE;

- wśród zagrożeń dla bezpieczeństwa Holandii (chociaż tak nie nazwanych) wskazano podatność na niepokoje społeczne związane np. z terroryzmem, cyberatakami, migracją czy nawet upadkiem Wenezueli i związanymi z tym ryzykami dla terytoriów na Karaibach (np. handel narkotykami, ludźmi), wzmacnianie sił zbrojnych Federacji Rosyjskiej i jej aktywność wojskową oraz ,zagrożenia hybrydowe", niestabilność w regionach sąsiadujących z Europą, nowe technologie, działania hybrydowe i proliferację broni masowego rażenia (Ministry of Defence, 2018, s. 8);

- celem władz jest zapewnienie bezpieczeństwa Holandii, promocja bezpieczeństwa w sąsiednich regionach i utrzymanie statusu Holandii jako bezpiecznego hubu komunikacyjnego;

- uznano, że by to osiągnąć w wymienionych warunkach, konieczny jest wzrost wydatków na obronność od 2021 roku o 1,5 mld $€$ rocznie, natomiast w 2019 roku o 1,2 mld $€$, a w 2020 o 1,4 mld €, łącznie zaś w latach 2018-2033 przeznaczenia nań 40 mld $€$, z tego na inwestycje od 2,5 do 2,8 mld $€$ rocznie. Jednak w stosunku 
do PKB założono wydatki na poziomie 1,25\% osiągnięte w 2022 roku. Rząd holenderski przyznał, że jest to zbyt mało by spełnić wszystkie oczekiwania NATO;

- jako priorytety rozwojowe sił zbrojnych określono rozbudowę zdolności do rozmieszczenia sił zbrojnych w miejscach, w których będzie to konieczne, ze względu na szybko zmieniające się środowisko bezpieczeństwa, modernizację posiadanego uzbrojenia, ponieważ przeciwnicy doskonalą swoje uzbrojenie, rozbudowę infrastruktury IT niezbędnej ze względu na rozwój technologiczny i pojawiające się szanse i zagrożenia dla bezpieczeństwa;

- program inwestycji w siły zbrojne został przedstawiony w szczegółowej tabeli, której zawartość wskazuje, zgodnie z przyjętym priorytetem, że w pierwszej kolejności będzie modernizowany już posiadany sprzęt, a dopiero w drugiej dojdzie do zakupów nowego uzbrojenia (Ministry of Defence, 2018, s. 28);

- największą część inwestycji przewidzianych w Białej Księdze pochłonie marynarka wojenna, dla której przewidziano zakup m.in. nowych okrętów podwodnych i fregat, co pochłonie ok. 15 mld $€$, zatem blisko 1/3 kwoty na inwestycje do 2033 roku. Ponadto zdecydowano o zakupie samolotów F-35 oraz modernizacji licznych systemów uzbrojenia wojsk lądowych.

Wspomniany priorytet dotyczący zdolności do rozmieszczania sił nie przekłada się jednak na budowę dużych zdolności w tym zakresie. Założono np., że holenderska marynarka wojenna będzie zdolna do operowania przez ograniczony czas w zespole 5 okrętów, to samo dotyczy sił lądowych wielkości brygady, natomiast wielkości batalionu dłuższy okres czasu (Ministry of Defence, 2018, s. 17). W wypadku sił lotniczych 8 F-16 będzie mogło operować ograniczony czas, 4 dłuższy. Po zakupie samolotów F-35 podobnie 4 maszyny przewidziano do udziału w dłuższych operacjach (Ministry of Defence, 2018, s. 18). Można stwierdzić, że nie są to plany ambitne i na pewno nie odpowiadają oczekiwaniom wielu sojuszników z NATO. Nie mogą bowiem podnieść w sposób zasadniczy zdolności sił zbrojnych Holandii, a tym samym zdolności do kolektywnej obrony państw NATO. Tym bardziej, że priorytetem dla władz jest marynarka wojenna. W wypadku NATO rozbudowa sił zgodnie z przedstawionym planem ma pozwolić na wysuniętą obecność, ale tylko sił lekkich, co ilustruje dobitnie infografika zamieszczona w Białej Księdze przedstawiająca lekki pojazd bojowy (Ministry of Defence, 2018, s. 10). Generalnie zaś autorzy Białej Księgi na pierwszym miejscu umieścili personel sił zbrojnych, w szczególności warunki służby, możliwość kariery itp. Wskazuje to jednoznacznie, że władze starają się przedstawić wzrost wydatków na obronność w taki sposób, by był on akceptowalny dla obywateli. Ludzie są zatem przed uzbrojeniem i ich dobro jest najważniejsze. To podejście, cechujące państwa Zachodu, wykorzystywane jest przez jego przeciwników.

Przedstawione założenia w Białej Księdze są realizowane przez władze. Dla przykładu rozpoczęto modernizację artylerii i wzmocnienie jej siły poprzez zakup w USA precyzyjnych pocisków Excalibur i zamówienie innego typu 3,5 tys. precyzyjnej amunicji za $70 \mathrm{mln}$ \$ (Palowski, 2018). Są to zdolności bardzo użyteczne do działań lądowych i ich pozyskanie wynika z wniosków działań zbrojnych na Ukrainie. Przywrócono do służby jedną kompanię czołgów służącą w ramach jednostki niemiecko-holenderskiej. Te działania można uznać za element odbudowywania zdolności konwencjonalnych użytecznych do działań w konflikcie na kontynencie europejskim, 
ale nie tylko. Ponadto podpisano umowę na zakup w USA systemu samolotów bezzałogowych MQ-9 Reaper Block 5 wraz z czterema płatowcami za ok. $340 \mathrm{mln} \$$ (Malicki, 2018). Podpisano także kontrakt na modernizację systemów Patriot. Jak widać z podanych przykładów, beneficjentem szeregu kontraktów są firmy amerykańskie, co nie oznacza, że władze holenderskie nie pamiętają o przemyśle europejskim np. współpracując w zakresie modernizacji marynarki wojennej z Belgią oraz przygotowując strategię udziału własnego przemysłu w procesie modernizacji sił zbrojnych.

Podsumowując, wspomniane nakłady przewidziane przez autorów Białej Księgi, można skonfrontować z wykorzystywanymi w tekście danymi NATO. Zgodnie z nimi w 2014 roku wydano 7,788 mld $€$, a na 2018 rok założono 10,701 mld euro. Zatem nastąpi znaczny wzrost wydatków, chociaż trzeba pamiętać, że z bardzo niskiego poziomu. Przy tym kluczowy dla niej jest wzrost pomiędzy 2017 a 2018 rokiem, ponieważ sięgnie nieco ponad 2 mld $€$. Wskazuje zatem na realizację przyjętych założeń obronnych w warstwie finansowej. Wzrost widać także wyraźnie w udziale w PKB, w 2014 roku wynosił 1,15\%, w 2015 - 1,12\%, w 2016 - 1,15\%, w 2017 - 1,16\% i w 2018 - 1,35\% (Defence Expenditure, 2018). Daleko mu do 2\% PKB, jednak oznacza to znaczące zwiększenie wydatków celem realizacji skromnego, ale jednak programu rozwoju sił zbrojnych i zdolności obronnych, a nie ich ograniczania, co miało miejsce do 2015 roku.

\section{Region Poludniowy, Wlochy}

Państwo znajdujące się w bardzo trudnej sytuacji gospodarczej, zmagające się z licznymi problemami, m.in. długu publicznego, nie jest liderem w podnoszeniu zdolności obronnych. Mimo, że w 2013 roku zaplanowano wzrost wydatków obronnych, to już w 2015 roku przeznaczono na nie o miliard $€$ mniej niż zakładano (Palowski, 2014). Jednak w kolejnych latach doszło do ich wzrostu, co było związane z bliskością zagrożeń i próbami wdrożenia zmian w polityce obronnej. Jeśli uwzględnić Brexit, to były to trzecie co do wielkości wydatki w całej UE. Utrzymująca się od wielu lat redukcja wydatków obronnych traktowanych jako rezerwuar środków na inne cele, sprawiła, że rząd włoski zdecydował o zmniejszeniu liczby posiadanych czołgów do 150, a parlament wnioskował o ograniczenie wielkości zamówienia na samoloty F-35 z 90 do 45 (Włochy kupia, 2014). Była to rekomendacja komisji podjęta w 2014 roku, zatem roku strategicznego zaskoczenia, które pobudziło wiele rządów do działań przeciwnych. We Włoszech zaś zamiast dozbrojenia rozpoczął się proces redukcji posiadanego sprzętu. W 2015 roku zdecydowano się na sprzedaż m.in. zmagazynowanych czołgów Leopard 1, haubic samobieżnych M109 i wozów wsparcia ogniowego Centauro (Włochy sprzedaja zmagazynowane czołgi, 2015). Mimo, że był to sprzęt starszy, to nadal sprawny, jednak koszty jego utrzymania uznano za zbyt wysokie. Podobnie rzecz miała się np. w Niemczech, których rząd także zdecydował się na sprzedaż samolotów MiG 29 i czołgów Leopard do Polski uznając, że jest to sprzęt zbędny, stary, którego koszty utrzymania i złomowania byłyby zbyt duże. Nie wszystko jednak co sprzedawano, można uznać za stare i przestarzałe np. wozy Centauro, co wskazywało jednoznacznie na ekonomiczne źródła tego przedsięwzięcia, za czym poszło zmniejszenie zdolności obronnych. Tego 
typu działania doraźne, w sytuacji wzrostu zagrożenia, dla Włoch szczególnie od strony południowej, sprawiły, że rząd zdecydował się przyjąć w 2015 roku Białą Księgę Obronną (The Ministry of Defence, 2015), której zawartość miała być odpowiedzią na zmiany w środowisku międzynarodowym, z uwzględnieniem włoskich uwarunkowań i oczekiwań sojuszników z NATO i partnerów z UE. Tym istotniejszą, że był to pierwszy tej rangi dokument od 13 lat. Zatem wydarzenia na Ukrainie, a z włoskiej perspektywy przede wszystkim w regionie Morza Śródziemnego i ich konsekwencje wpłynęły na postrzeganie polityki obronnej i uzmysłowiły konieczność jej przeglądu. Co ciekawe, po raz pierwszy przygotowanie dokumentu było szeroko konsultowane, nie tylko w ramach rządu (z innymi ministrami), ale i organizacjami, uczelniami itp. W sposób syntetyczny jej zawartość wygląda następująco:

- na włoską obronność wpływają m.in. zmiany zachodzące w środowisku międzynarodowym potęgowane przez proces globalizacji (np. słabnięcie państwa), w szczególności zakłócenia globalnej równowagi sił oraz liczne konflikty o różnym podłożu powodujące niestabilność międzynarodową, olbrzymi postęp technologiczny niosący ze sobą szereg zagrożeń, zmiany demograficzne i urbanizacja, rywalizacja o surowce naturalne, zmiany klimatu oraz niskie wydatki na obronność (The Ministry of Defence, 2015, s. 21-25). Co ciekawe, w całym dokumencie nie wymieniona jest z nazwy Federacja Rosyjska, czego można byłoby oczekiwać np. w części poświęconej bezpieczeństwu globalnemu. W kontekście zagrożenia atakiem hybrydowym mowa jedynie o aktorach transnarodowych, co nie powinno dziwić biorąc pod uwagę położenie, ale przede wszystkim relacje włosko-rosyjskie. Wobec tego zagrożenie konwencjonalne w regionie Euro-Atlantyckim autorzy Białej Księgi szacują na mało prawdopodobne, ale jednak nie wykluczone (The Ministry of Defence, 2015, s. 37);

- głównym celem rządu jest ochrona strategicznych interesów Włoch, w pierwszej kolejności suwerenności i integralności terytorialnej, dalej bezpieczeństwa regionalnego (region Euro-Atlantycki i Euro-Śródziemnomorski) i międzynarodowego. Siły zbrojne zaś mają koncentrować się na obronie terytorium państwa, realizacji zobowiązań międzynarodowych Włoch oraz pomocy społeczeństwu np. w wypadku klęsk żywiołowych;

- NATO traktowane jest jako klucz do bezpieczeństwa Włoch ze względu na zdolności do odparcia jakiejkolwiek agresji, UE pozostaje ważną organizacją i rząd jest gotowy do głębszej integracji w dziedzinie obrony, natomiast ONZ jest ważne ze względu na stanie na straży ładu międzynarodowego opartego na prawie, Włochy pozostają w pierwszej 10 płatników organizacji i państwem aktywnym na rzecz realizacji operacji pokojowych. Co za tym idzie i jest to mocno podkreślone w Białej Księdze, przewidziana jest możliwość rozmieszczenia sił zbrojnych poza terytorium Włoch w obronie ich interesów oraz w ramach operacji UE, NATO i ONZ. Generalnie zaś, dużej partycypacji w różnego rodzaju operacjach międzynarodowych. Z tego musi zatem wynikać zdolność do szybkiego reagowania i rozmieszczenia, jaką muszą mieć siły zbrojne, łącznie ze stworzeniem części Sił Rezerwy nazwanej „rezerwą operacyjną” (The Ministry of Defence, 2015, s. 57);

- region Morza Śródziemnego, a szerzej „Euro-Mediterranean”, w którym ulokowano m.in. problem terroryzmu (The Ministry of Defence, 2015, s. 38) jest klu- 
czowy dla Włoch, dlatego siły zbrojne mają być zdolne do odgrywania wiodącej roli w operacjach międzynarodowych tam prowadzonych, nawet w wypadku kryzysów na dużą skalę, zatem jest to założenie ambitne. Jednak jako o pierwszym regionie autorzy dokumentu wspominają Euro-Atlantycki, w którym ulokowane jest 68\% włoskiego importu i 75\% eksportu (The Ministry of Defence, 2015, s. 26). Tym samym potwierdzone zostają także zobowiązania związane z członkostwem w NATO. Wspomnienie tego regionu jako pierwszego jest kluczowe ze względu na gwarancje bezpieczeństwa oraz jego pozycję ekonomiczną;

- redukcja liczebności sił zbrojnych z 190 tys. do 150 tys. do 2025 roku, zgodnie z prawem przyjętym w 2012 roku;

- konieczna jest lepsza współpraca przemysłów obronnych państw UE, którą należy pogodzić z wymogami związanymi z bezpieczeństwem narodowym państw członkowskich (np. wyłączności na pewne technologie itp.). Celem winna być specjalizacja przemysłów obronnych i ich uzupełnianie się, najlepiej w wymiarze wielostronnym, a nie tylko bilateralnym. Szerzej zaś chodzi o pogłębianie współpracy obronnej państw UE;

- by sprostać przedstawionym uwarunkowaniom i celom sfera polityki obronnej ma zostać poddana czterem kluczowym reformom: zarządzania (ze względu na zbyt rozbudowane struktury organizacyjne, z czasów o wiele liczniejszej armii z poboru skomplikowany proces decyzyjny na poziomie politycznym i utrudnione relacje między kierownictwem politycznym a wojskowym itp.), reorganizacji modelu operacyjnego (z powodu np. dublowania się kompetencji i struktur itp., konieczności centralnego podejścia do zamówień dla wojska, stworzenia Dowództwa Połączonego itp.), personelu (np. umożliwienie przyjęcia do służby przygotowawczej (temporary) 22-latkom, zamiast 25-latków i określenie ścieżek kariery prowadzących do służby stałej, tak by komponent operacyjny sił zbrojnych, zdolny do rozmieszczenia nawet daleko od granic państwa składał się w $2 / 3$ z młodych osób, zmiany w szkoleniu np. zorientowanie na działania połączone) i zamówień (ze względu na postęp technologiczny inwestycje winny być realizowane w okresie 6-letnim, co trzy lata dokonywanie przeglądu i na tyle lat planowanie środków na nie, większy udział parlamentu w pracach nad tymi kwestiami, koordynacja badań i zamówień, co oznacza silne zaangażowanie koordynowane centralnie przemysłu, instytucji badawczych itp.).

Biała Księga jest to rozbudowany, 124-stronicowy dokument, w porównaniu do holenderskiego, liczącego 30 stron, jest kompleksowy, jednak zbyt rozległy np. w charakterystyce współczesnych konfliktów zbrojnych. Można jednak uznać, że miał pokazać wynik prac szeregu osób i stanowić podstawę do działań legislacyjnych. W ciągu 6 miesięcy miano przygotować Strategiczny Przegląd Obronny, zawierający m.in. priorytety w obszarze modernizacji sił zbrojnych i projekt konkretnych zmian celem przedstawienia ich Parlamentowi i ich uchwalenia. Niestety nie udało się dotrzymać tego terminu i dopiero blisko dwa lata po wydaniu Białej Księgi trafił on pod obrady, co było spowodowane priorytetem innych kwestii oraz wynikającymi z sygnalizowanych reform oszczędnościami dzięki redukcji zbędnych instytucji i personelu, co nie cieszy się zwykle poparciem wielu parlamentarzystów ze względu na ich koszty społeczne, tym istotniejsze, że zbliżały się wybory parlamentarne, po których procedowa- 
nie nowego prawa musiałoby zacząć się od początku. Wobec tego los reformy będzie leżał już w rękach nowego rządu ukonstytuowanego w 2018 roku. Istota problemu leży w finansowaniu zmian i ciągłym ograniczaniu wydatków na obronność. $Z$ tego też względu, podobnie jak w Holandii, modernizuje się np. śmigłowce szturmowe, a nie kupuje nowe. Zakupy zaś są skromne np. w 2018 roku kupiono 10 pojazdów bojowych Centauro II. Wartość kontraktu wyniosła około $159 \mathrm{mln} €$. Wprowadzono też na wyposażenie szybką łódź dla komandosów z Operacyjnej Grupy Szturmowej (Operational Raiders Group) sił specjalnych włoskiej marynarki wojennej. Realizowano natomiast intensywnie zadania związane z udziałem w operacjach międzynarodowych np. w latach 2014-2017 Włochy wspięły się na drugie miejsce wśród państw koalicji pod przewodnictwem USA walczącej z ISIS z wkładem m.in. 1500 żołnierzy i 420 pojazdów. Chcąc sprostać oczekiwaniom sojuszników z NATO w związku z ich obawami o politykę Federacji Rosyjskiej włoskie siły zbrojne objęły odpowiedzialność za dyżur Sił Odpowiedzi NATO w 2018 roku (Włosi sami się zgłosili do tego zadania). Wysłali też 200 żołnierzy do Estonii w ramach wysuniętej obecności NATO. Dowodzi to, że Włosi poważnie traktują swoje zobowiązania, nawet jeśli finansowanie sił zbrojnych pozostawia wiele do życzenia. Wyjaśnienie tych faktów i celów jest podobne jak w Polsce. Włosi okazują solidarność mając nadzieję, że podobną okażą państwa NATO wobec ich problemów na Południu. Tam także są aktywni np. w Libanie, w Rogu Afryki, Nigrze czy we wspomnianej już walce z ISIS. Warto także wspomnieć o kontyngencie w Afganistanie liczącym 1000 żołnierzy, dwa razy większym niż brytyjski. Ponadto zaangażowaniu w misje na Morzu Śródziemnym w związku ze zwalczaniem handlu ludźmi, nielegalnej migracji itd. (Marrone, 2018). Siły zbrojne mają więc silny charakter ekspedycyjny i takie też mają pozostać zgodnie z przedstawioną koncepcją, jako środek do realizacji celów włoskiej polityki obronnej, a szerzej interesów narodowych.

Podsumowując, Biała Księga jest dokumentem kompleksowym, spójnym (np. łączy priorytet operacyjności z wyposażeniem i personelem, wskazując na konieczność jego odmłodzenia) i jako taka wymaga także kompleksowego wdrożenia, poczynając od systemu kierowania i dowodzenia siłami zbrojnymi, przez modernizację i zakupy uzbrojenia, a kończąc na współpracy z przemysłem i zapleczem intelektualnym ulokowanym np. na uniwersytetach. Na razie jednak środki przeznaczane na obronność, a szerzej sytuacja ekonomiczna, nie sprzyja całościowej realizacji tego projektu. Nawet jeśli wzrosły one po 2015 roku. Zgodnie z danymi NATO w 2014 roku wynosiły 18,427 mld €, w 2015 - 17,642 mld €, a w 2018 mają wynieść 21,183 mld €. Jako procent PKB jest to odpowiednio: 1,08\%, 1,01\% i 1,15\% (Defence Expenditure, 2018). Zatem daleko przed progiem oczekiwanym przez NATO, ale z utrzymaniem dotychczasowej polityki.

\section{Zakończenie}

Przeprowadzona analiza dowodzi, że strategiczne zaskoczenie roku 2014 zweryfikowało politykę obronną wielu państw i nadało jej nowy impuls w kierunku odbudowy utraconych zdolności obronnych. Proces ten nie będzie jednak szybki i istnieje 
duże ryzyko polityczne jego powodzenia wynikające z sytuacji gospodarczo-społecznej państw europejskich. Z całości dociekań można wyciągnąc szereg wniosków:

1. Zgodnie z przyjętym podziałem na regiony opartym na danych EDA można stwierdzić, że państwa Europy Wschodniej zwiększają wydatki na obronność, nie tylko pod względem nominalnym, ale i wielkości PKB, czego przykładem jest Polska i przyjęte rozwiązania prawne na przyszłość np. dotycząca gwarancji wydatkowania 2,5\% PKB. Potwierdzają to dane z innych państw regionu np. Bałtyckich czy Rumunii.

2. Przykład Finlandii, wskazuje, że państwa tego regionu podjęły działania mające na celu efektywniejsze wydawanie przekazywanych na obronność środków finansowych oraz zatrzymały proces ich obniżania, co nominalnie przekłada się na ich wzrost. Ogłoszono podjęcie kroków mających rozbudować zdolności sił zbrojnych czy to poprzez zwiększenie możliwości mobilizacyjnych i rozwój obrony terytorialnej (jak w Finlandii) czy przywrócenie poboru do wojska (jak w Szwecji, nawet jeśli ograniczonego).

3. Państwa Europy Zachodniej, na przykładzie Holandii, przyjęły rozwiązania oparte na uaktualnieniu założeń polityki obronnej i asygnowaniu na nią większych środków, w wypadku Holandii powstrzymanie procesu spadku łączy się ze znacznym nominalnym wzrostem do czasów sprzed kryzysu i wieloletnim planem inwestycji w modernizację sił zbrojnych. Jednak stawiane cele w zakresie zdolności są ograniczone i niewystarczające w wypadku ewentualnego konfliktu konwencjonalnego o dużej skali. Priorytetem, ze względu na koszty, jest modernizacja, a dopiero w drugiej kolejności zakup nowego sprzętu. Co ciekawe, przykłady kontraktów pokazują, że rynkiem pozyskiwania sprzętu są USA, a najdalej idące plany dotyczą rozwoju marynarki wojennej, z uwzględnieniem współpracy w tej dziedzinie z państwami regionu.

4. Przykład Włoch pokazuje dobitnie, jak problemy gospodarcze przekładają się na stan sił zbrojnych. Mimo polityki oszczędności Włochy pozostawały w czołówce państw UE pod względem wydatków na obronność, jednak pod względem PKB daleko im do wartości uznawanej za wystarczającą dla NATO. Wzrost zagrożeń na południu sprawił, że to państwo stało się jeszcze bardziej aktywne w obszarze misji zagranicznych, co na przyszłość potwierdził dokument określający ambitnie zmiany niezbędne w polityce obronnej w najbliższych latach. Jednak realizacja zawartych tam założeń $\mathrm{w}$ obecnej sytuacji ekonomicznej jest mało prawdopodobna.

5. We wszystkich z wybranych państw doszło do publikacji nowych koncepcji polityki obronnej. Różni je jednak zawartość, zależnie od uwarunkowań w jakich kreowana jest owa polityka, zarówno obiektywnych, jak i subiektywnych. Te drugie w niektórych przypadkach mogą być kluczowe, jak ma to miejsce w Polsce. Stąd m.in. postrzeganie Federacji Rosyjskiej jako głównego sprawcy zagrożeń dla bezpieczeństwa jest tak różne w Polsce i we Włoszech. $Z$ drugiej strony państwo wspominane jest bardzo oszczędnie w dokumencie holenderskim, którego zawartość bardziej sugeruje pewne kwestie z tym związane niż podaje je wprost.

6. Państwa frontowe, za które można uznać Polskę i Włochy prowadzą podobną politykę w obszarze ekspedycyjności, a ściślej rzecz biorąc prowadziły. Podczas gdy Włochy ciągle traktują ją priorytetowo, to w Polsce na pierwszym miejscu posta- 
wiono obronę własnego terytorium przed atakiem hybrydowym i konwencjonalnym. Niezależnie od tego oba państwa widzą w okazywaniu wsparcia sojusznikom narzędzie do tego, by zwiększać prawdopodobieństwo jego udzielenia przez nich w sytuacji, gdyby zaszła taka potrzeba. Tym sojusznikiem mają być przede wszystkim USA, ale rzecz jasna Włosi o wiele silniej akcentują także państwa UE i wnoszą o rozwój jej polityki bezpieczeństwa i obrony.

7. Wielkość nakładów na obronność we wszystkich państwach znacząco odbiega od oczekiwań NATO, jak i stanów określonych w układzie o konwencjonalnych siłach zbrojnych w Europie. Co za tym idzie, większość państw europejskich ma przed sobą duży dystans do nadrobienia by można było mówić o rzeczywistym wzroście ich zdolności obronnych. Nie da się tego wykonać jedynie nie obniżając wydatków i podnosząc je dzięki wzrostowi PKB. Potrzebne są odważniejsze programy obronne, do których przekonać trzeba społeczeństwa. Może to uczynić tylko realne poczucie zagrożenia, lub wydarzenia rzutujące na percepcję stanu bezpieczeństwa międzynarodowego i jego skutków dla życia codziennego, jak miało to miejsce z zestrzeleniem samolotu malezyjskich linii lotniczych nad Ukrainą i udowodnieniem przez zespół śledczych, że odpowiedzialność za to spoczywa na Federacji Rosyjskiej.

8. W związku z odwróceniem tendencji spadkowej w wydatkach obronnych pojawia się kwestia tego, jakie przedsiębiorstwa i państwa będą beneficjentami programów modernizacji i zakupów nowego sprzętu. Stąd m.in. podnoszona kwestia intensyfikacji współpracy przemysłów obronnych państw UE, a nawet ich specjalizacji i związanych z tym zakupów realizowanych pomiędzy poszczególnymi uczestnikami rynku. Nie jest to rzecz prosta nie tylko ze względów technologicznych, ale i bezpieczeństwa narodowego ze względu na związane z tym kwestie wyłączności na określone technologie itp. Do tego istotna jest kwestia stosunku do USA i zakupów w tamtejszych firmach, które mogą być traktowane jako karta w przetargu politycznym opartym na prostym schemacie. Jeśli nawet nie wydamy $2 \%$ PKB na obronność, to przynajmniej kupujemy broń w amerykańskich przedsiębiorstwach. Wobec tego ewentualna krytyka ze strony administracji USA może mieć tylko charakter symboliczny.

9. Wzrost wydatków nie gwarantuje szybkiego przyrostu zdolności obronnych. Przemysł zbrojeniowy nie realizuje kontraktów w szybkich terminach, szczególnie w sytuacji dużych zamówień. Dodatkowo zaś przykład Holandii i Polski pokazuje różnicę w sprawności realizacji zamówień wojskowych. W wypadku tego pierwszego państwa wszystko rozpisane jest ze szczegółami, transparentnie, zaplanowane w taki sposób, by rzecz można było zrealizować terminowo, za co odpowiadają odpowiednie instytucje i procedury. W wypadku Polski, co pokazuje doświadczenie nie tylko ostatnich lat, przetargi się przeciągają, kontrakty są odwoływane, budowa nowego sprzętu może trwać wiele lat dłużej itp. To pokazuje różnice nie tylko mentalności, ale i systemu organizacyjnego, w jakim funkcjonują oba państwa, a w tym wypadku w szczególności resorty obrony i jego instytucje. W związku z tym konieczne są zmiany, które w Polsce, a szerzej w państwach regionu, usprawnią realizację zadań z zakresu polityki obronnej, co wiąże się ze zmianami personalnymi (zarówno wśród cywilów, jak i wojskowych) oraz systemowymi. 


\section{Bibliografia}

2018 Defence White Paper. Investing in our people, capabilities and visibility (2018), Ministry of Defence.

Brune S. Ch., Mölling Ch. (2011), The Impact of the Financial Crisis on European Defence, European Parliament, Brussels.

Defence Data 2016-2017. Key Findings and Analysis (2018), European Defence Agency, s. 6.

Defence Expenditure of NATO Countries 2011-2018 (2018), Press Release 091, https://www.nato. int/nato_static_fl2014/assets/pdf/pdf_2018_07/20180709_180710-pr2018-91-en.pdf.

Finnish Reserve Training. Military service is an essential part our defense solution (2017), Training Division (J7), Defence Command, http://www.erok.ee/uploads/files/finnish_reserve_training_system_est_conference.pdf.

Government's Defence Report (2017), Prime Minister's Office Publication, 7/2017, Helsinki.

Järvenpää P. (2016), Preparing for the worst. Conscription and reserve forces in the Nordics, RKK ICDS, https://www.icds.ee/fileadmin/media/icds.ee/failid/ICDS_Analysis_-_Preparing_for_ the_Worst__Pauli_Jarvenpaa.pdf.

Klisz M., Lasoń M. (red.) (2017), Wojska Obrony Terytorialnej w Polsce i na świecie w drugiej dekadzie XXI wieku, „Bezpieczeństwo. Teoria i Praktyka”, nr 3.

Kołek P. (2017), Sity zbrojne Niderlandów po zimnej wojnie. Przekształcenia-problemy-perspektywy, Wydawnictwo Adam Marszałek, Toruń.

Koncepcja Obronna Rzeczypospolitej Polskiej (2017), Ministerstwo Obrony Narodowej, https:// www.gov.pl/documents/1445950/1446226/korp_web_13_06_2017.pdf/27c65d5b-14943547-cd0f-7bbf0902045b.

Kubiak K. (2016), Poheroiczny Zachód wobec wyzwań militarnych pierwszych dekad XXI wieku, w: Czynnik wojskowy w środowisku międzynarodowym na przełomie XX i XXI wieku, red. Ł. Jureńczyk, S. Sadowski, M. Jastrzębski, J. Waskan, Wydawnictwo Uniwersytetu Kazimierza Wielkiego, Bydgoszcz, s. 24-27.

Malicki P. K. (2018), Farnborough: Holandia kupuje MQ-9 Reaper, 18.07.2018, Defence24.pl, https://www.defence24.pl/farnborough-2018-holandia-kupuje-mq-9-reaper, (29.09.2018.

Marrone A. (2018), Italy's Defence Policy: What to Expect from the 2018 Elections?, IAI, 18I05, http://www.iai.it/en/pubblicazioni/italys-defence-policy-what-expect-2018-elections, 30.09.2018.

National Defence is everybody's business (2017), The Finnish Defence Forces, http://puolustusvoimat.fi/documents/1948673/2267766/PV_Maanpuolustus_taskuesite_0317_EN_www_final.pdf/51814168-991d-4ab4-ab99-d3fb2d794829/PV_Maanpuolustus_taskuesite_0317_ EN_www_final.pdf.pdf.

Palowski J., Holandia wzmacnia artylerię. 3,5 tys. precyzyjnych pocisków, 27.04.2018, Defence24. $\mathrm{pl}$, https://www.defence24.pl/holandia-wzmacnia-artylerie-35-tys-precyzyjnych-pociskow, 29.09.2018.

Palowski J., Holandia zwiększa wydatki obronne, 17.09.2014, Defence24.pl, www.defence24.pl/holandia-zwieksza-wydatki-obronne, 29.09.2018.

Palowski J., Włochy zmniejszaja wydatki obronne, 30.12.2014, Defence24.pl, https://www.defence24.pl/wlochy-zmniejszaja-wydatki-obronne, 29.09.2018.

Share of defence budget of GDP, Ministry of Defence, https://www.defmin.fi/en/tasks_and_activities/resources_of_the_defence_administration/finances/share_of_defence_budget_of_gdp, 3.10.2018.

White Paper for international security and defence (2015), The Ministry of Defence.

Włochy kupia o połowę mniej myśliwców F-35, 8.05.2014, Defence24.pl, https://www.defence24.p1/ wlochy-kupia-o-polowe-mniej-mysliwcow-f-35, 30.09.2018. 
Włochy sprzedaja zmagazynowane czotgi i haubice, 20.03.2015, Defence24.pl, https://www.defence24.pl/wlochy-sprzedaja-zmagazynowane-czolgi-i-haubice, 30.09.2018.

\section{Streszczenie}

Celem artykułu jest wskazanie relacji pomiędzy wydarzeniami, które miały miejsce na Ukrainie w 2014 roku i latach następnych, a zmianami w politykach obronnych wybranych państw Unii Europejskiej. Autor zakłada, że przynajmniej część z państw należących do Unii Europejskiej zmieniła swoją politykę obronną. Ograniczyła redukcję wydatków obronnych, a nawet rozpoczęła ich zwiększanie. Szczególnie w państwach graniczących z Federacją Rosyjską. Weryfikację tej hipotezy można przeprowadzić w oparciu o publikowane w latach 2014-2017 białe księgi obronności, lub dokumenty o tożsamym charakterze. Ponadto poprzez wskazanie działań (lub ich braku) realizowanych przez rządy państw zgodnie z przyjętymi założeniami. Za właściwą perspektywę badawczą uznano podejście neorealistyczne.

Słowa kluczowe: Unia Europejska, polityka obronna, siły zbrojne, Finlandia, Polska, Holandia, Włochy

\section{Changes in the defense policy of selected European Union countries in 2014-2017}

\section{Summary}

The aim of the article is to identify and analyse the relationship between events in Ukraine in 2014 and changes in defense policies of selected European Union countries. The author assumes that at least some of the countries belonging to the European Union have changed their defense policy. They limited the reduction of defense expenditures and even started to increase them. Especially countries bordering on the Russian Federation. Verification of this hypothesis can be carried out on the basis of defense white papers published in 2014-2017 or similar documents. Moreover, by analyse of the actions which have been taken to implement the adopted assumptions. The neorealistic approach was considered to be the right research perspective.

Key words: European Union, defense policy, armed forces, Finland, Poland, Netherlands, Italy 
